\title{
Changing Perceptions on PPP Games: Demand Risk in Irish Roads
}

\begin{abstract}
This study is based on three Irish operational toll road Public Private Partnership (PPP) case studies, including interviews with 38 key stakeholders. Our findings show that the Irish Government's treatment of risk and its transfer to the private partner in PPPs are changing over time. Regulatory changes, which have led to increased finance costs, coupled with a severe global economic crisis, have exacerbated the difficulties in funding PPPs. The goalposts in Irish PPPs appear to be changing in favour of the private partner at the expense of the taxpayers, who are the losers in the PPP game. The Government are suggesting that they may potentially step in, if projects experienced financial difficulty and the Special Purpose Vehicle (SPV) may require specific guarantees in order to participate in future PPP projects. Pricing of demand risk also differs from the Government's rhetoric that it is being priced realistically. In practice, we find that it is priced aggressively by the SPV in order to win PPP contracts. The paper discusses the possible implications of these findings for Value for Money (VFM) and, ultimately, taxpayers.
\end{abstract}

Keywords: Public Private Partnerships, Value For Money, Change in Perceptions, Demand Risk Allocation and Transfer, Estimating Demand Risk, Toll Roads.

\section{Introduction}


When Public Private Partnerships (PPPs) ${ }^{1}$ were first conceived risk management was not considered as one of the main issues by the public sector (Demirag et al., 2010). Recent empirical studies on PPPs, have, however highlighted the importance of examining attitudes to risk, as risk has emerged as one of the crucial considerations in justifying and transferring more public services to the private sector. The assessment and transfer of risk in PPPs largely determines whether or not a project is Value for Money (VFM) (Froud, 2003; Grimsey and Lewis, 2005; Demirag and Khadaroo, 2008). Broadbent et al. (2008) posit that the real challenge in determining VFM in PPP contracts lies with the calculation of retained risk by the public sector and the value of the transferred risk to the private sector as both involve subjective and qualitative judgements. Moreover, the lack of data collection to systematically evaluate whether PPP schemes provide effective risk transfer and represent VFM compared to other forms of procurement was also criticised in a recent National Audit Office (NAO) report (NAO, 2011). Arguably risk should be managed by the party who is better able to control risk factors (Froud, 2003) or is willing to bear it (Li et al., 2005; Hood et al., 2006).

Prior literature on PPP risks have examined risk as a generic concept (Roumboutsos and Anagnostopoulos, 2008), and from primarily senior debt provider's perspectives (Asenova and Beck, 2010). There is a dearth of literature examining perceptions of key stakeholders on how risk is actually transferred and priced in PPP contracts and why some key players have different interests and perceptions. For example, there is some evidence to suggest that in Australia the private sector has recently assumed more of the demand risk ${ }^{2}$ (Brown, 2005) because the guarantees provided by the Australian Government reduced significant uncertainty (AlonsoConde et al., 2007). Others have argued that the private sector was inept at managing demand risk and this may have been one of the reasons why the downside demand risk ${ }^{3}$ was underwritten by the state (Acerete et al., 2010). More recently, Jupe (2011) examined publicly available documentary evidence in four UK transport case studies and concluded that the risk transfer from the Government to the private sector had not been substantial or effective, and the public

\footnotetext{
${ }^{1}$ Shaoul et al. (2012a, p.214) provide a definition of PPPs as 'clearly defined projects, the risks and rewards of which are shared between the public and private sectors. That is usually a long-term relationship between a public sector procurer and multiple private sector companies exists to design and construct infrastructure, maintain it and provide some related services'.

${ }^{2}$ Demand risk can be difficult to define and is often subject to diverse interpretations. For the purposes of this study our working definition for demand risk is the difference between anticipated and expected level of traffic volume (Shaoul et al., 2007).

${ }^{3}$ This refers to when demand levels do not meet the expected levels in the SPVs bid estimates.
} 
sector effectively underwrote the projects and was the lender of last resort. However, none of these studies explore the perceptions of different types of financiers or Special Purpose Vehicle $(\mathrm{SPV})^{4}$ members.

Demirag et al. (2010) found that most of the risks assumed to be transferred to the SPV were in fact not managed by the SPV and instead were passed on to their subcontractors or privately insured. Given the level of risk diffusion by financiers to other stakeholders (Demirag et al., $2011,2012)$, it is interesting to study the extent to which risk diffusion is also evident in other PPP schemes, particularly in hard toll ${ }^{5}$ PPPs where a significant level of risk transfer from the public to the private sector occurs. Demirag et al. (2011) focused on financiers' perceptions of a number of risks in different sectors including roads, hospitals and education. This study extends this earlier work and contributes to the literature by examining the demand risk appetite of financiers and a number of other SPV members and key stakeholders in Irish road PPPs. The importance of demand risk is highlighted by the nature of the risk which, unlike other PPP risks examined in prior studies, cannot be passed on to other stakeholders as explained in detail later in this section. This paper attempts to fill this lacuna in research by examining the transfer and pricing of demand risk in three operational PPP toll road projects in Ireland.

The paper focuses on PPPs in the transportation sector since transport PPPs form the majority of PPP investment in Ireland (Ireland's National Development Plan, 2007), the UK (Shaoul et al.,2012b) and globally (Public Works Financing, 2011). Over 1000 PPP roads projects valued at \$US 679.9 billion have been financed through PPPs worldwide between 1985-2011 (Public Works Financing, 2011). According to a recent study by the European PPP Expertise Centre $(\text { EPEC })^{6}$ (2013a) the transport sector, was the most significant sector in terms of PPPs in 2012, with $€ 7$ billion in expenditure. This was more than treble the value of education PPPs, which was the second biggest sector (EPEC, 2013a). Price Waterhouse Coopers (2005) suggest that a number of countries implement PPPs in the transport sector initially in order to ascertain if they

\footnotetext{
${ }^{4}$ According to Demirag et al. (2011, p. 295) 'the SPV is normally owned by a consortium which, because of the holistic nature of the contracts, will typically include two or three companies with a range of skills necessary to finance, build and operate the required facilities. The SPV, which is usually a shell company, in turn subcontracts the finance, design, construction, maintenance and soft services to companies that are often related to shareholders'. ${ }^{5}$ Hard toll PPPs refer to PPPs whereby the user pays a toll to use the PPP road. The private sector is remunerated by the toll revenue that they receive from the user.

${ }^{6} \mathrm{EPEC}$ is an expertise centre formed as a joint initiative between the European Investment Bank (EIB), European Commission and EU member states. It shares expertise and best practice on PPPs with all its members (EPEC, 2013b).
} 
offer VFM and the public sector have the requisite experience before developing them in other sectors.

This study also makes an important contribution to PPP literature because demand risk in transport infrastructure PPPs is particularly different from other types of risks (which have been widely examined in prior literature), for two main reasons. Firstly, demand risk provides the basis for estimating expected income from tolls, which in turn determines the SPV's own bid for the PPP project. The lowest bid based on net present value will be successful. Secondly, unlike design, construction and operational risks that can be priced and managed by subcontractors, demand risk may not be transferred by the SPV to subcontractors (Demirag et al., 2012); subcontractors cannot control many of the variables that influence it, such as National Income and fuel prices, thereby inhibiting demand risk transfer to subcontractors. Other uncontrollable factors affecting demand risk include the inability of the SPV to set toll prices and alternative forms of transport being made available to road users.

This paper seeks to address three main research questions. Firstly, what are the key stakeholders' perceptions on how effectively demand risk is transferred from the public to the private sector in Irish hard toll PPPs? Secondly, what are the key stakeholders' perceptions on how demand risk is actually priced by the SPV in Irish hard toll PPPs ? Thirdly, has the Government changed its objectives on transferring risk from the public to the private sector?

The remainder of the paper is organised as follows. The next section provides a brief overview of PPPs in Ireland, followed by a summary of recent changes in the regulatory framework and how these have impacted on the PPP market. We then discuss the relevant prior literature on risk and uncertainty with particular emphasis on how demand risk is transferred and priced in different types of roads. This is followed by Governmental guidelines and documentation on how risk should be transferred and priced in PPPs. The next section discusses the research methods used and the findings of the study. Finally we discuss these findings and provide some concluding comments.

\section{An Overview of PPPs in Ireland}


PPPs were initially introduced in Ireland under the National Development Plan (NDP) in 1999 across a range of sectors including education and roads. PPPs have helped to significantly reduce Ireland's infrastructure deficit. A detailed analysis of PPPs in procurement and operation in Ireland can be seen on the Irish government's PPP website (http://ppp.gov.ie/) and more extensive detail on the roads sector can be found on the National Roads Authority (NRA) ${ }^{7}$ website (www.nra.ie). In the Republic of Ireland, a significant number of foreign firms with experience and international expertise have invested in Irish PPPs. An interdepartmental group on PPPs, as well as an informal advisory group, have also been established to develop the PPP process in Ireland. These groups comprise of a number of key stakeholders, including the private sector, unions and Government representatives (Public Private Informal Advisory Group, 2001) (See Figure 1 provided in Appendices for an overview of the key stakeholders involved in the Irish roads PPP sector).

The Republic of Ireland adheres to the guidelines produced by Eurostat in 2004 regarding the balance sheet treatment of PPPs. The assets of PPP projects that are privately funded are considered off balance sheet in the National Accounts (Department of Finance, 2006a, p.36). The construction costs will not impact on the General Government Balance upfront during the construction period, provided that the private sector partner is allocated the construction risk and bears either the demand or the availability risk. The unitary payments however will be considered as part of the General Government Balance expenditure in the years in which they are incurred over the contracts duration (Department of Finance, 2006a, p.36).

Under Ireland's NDP 2007-2013, €13.35 billion $^{8}$ has been earmarked for PPPs, with $€ 11.21$ billion being funded by unitary payments and just over $€ 1.9$ billion by user charges, primarily through toll charges in road PPPs. ${ }^{9}$ The transport sector, with approximately $€ 8.9$ billion (67\%)

\footnotetext{
${ }^{7}$ The NRA is a semi-state body responsible for procuring Irish roads. Under Section 17 of the Roads Act, 1993, the NRA is responsible for Irish National roads (Department of Transport Tourism and Sport, 2010).

8 This $€ 13.35$ billion refers to PPP capital investment. According to the report of the Comptroller and Auditor General (CAG) (2012) future contractual commitments in terms of PPPs are expected to be approximately $€ 6.4$ billion. The outstanding commitment in terms of NRA projects is $€ 1.689$ billion. These contractual commitments relate to operational payments on the PPPs over the life of the projects. Future costs in terms of traffic guarantees are not included in these estimates. The next tranche of PPPs in Irish roads will be based on unitary payments (CAG, 2012).

${ }^{9}$ Unitary payments refer to fixed payments paid by the public sector to the private sector in availability based PPPs over the period of the contract usually between 30-35 years. User charges refer to toll revenue recouped through toll charges by the private sector on toll based PPPs.
} 
of PPP capital expenditure, is the most important area in terms of the Irish PPP programme, with the improvement of the road network being seen as key to the continuing economic development of the country.

The total capital investment in the Irish National Development Plan is $€ 79.5$ billion with transport investment the largest area at $€ 32.914$ billion. PPP transport investment therefore represents $27 \%$ of overall transport investment and $11.2 \%$ of overall capital investment in the Irish National Development Plan (Ireland's National Development Plan, 2007). Subsequent to the NDP 2007-2013, the Government has recently announced a stimulus plan of a further $€ 1.4$ billion PPP investment aimed at creating employment and economic growth (Department of Public Expenditure and Reform, 2012).

We now turn our attention to some of the recent changes in the PPP regulatory market.

\section{Changes in the regulatory framework in the PPP market}

The recent global financial crisis may be the worst the world has experienced since the Great Depression (Claessens et al., 2010, p.269), as the magnitude of the crisis is evident by the fact that Government bailouts have not so far helped to solve it (Crotty, 2009, p.1). Ireland was not immune from this crisis, and in September 2008 it experienced a major domestic banking crisis due to the demise of Lehman Brothers, which exposed a gap of approximately $€ 200$ billion between bank loans and deposits (Thorhallsson and Kirby, 2012, p. 802). This was primarily due to Irish banks engaging in poor risk management practices (O Sullivan and Kennedy, 2010) and reckless activity. The inability to raise funds on international markets, coupled with budgetary pressures and poor regulation, contributed to Irelands economic and financial problems. In order to help resolve the crisis the Irish Government decided on a bailout, thus guaranteeing the liabilities of the banks (Thorhallsson and Kirby, 2012).

A number of significant economic factors, such as asset price inflation, disparities in current accounts, high leverage and credit becoming easily available, have made the crisis more acute worldwide (Claessens et al., 2010, p.270), and the availability of credit for the PPP market more difficult (Burger et al., 2009; Farquharson and Encinas, 2010; Connolly and Wall, 2011, OECD 2012). 
The global crisis has also engendered significant debate on risk management in the banking sector, which has led to considerable revision of regulatory frameworks (Vásquez and Federico, 2012, p. 3). Basel $\mathrm{III}^{10}$ was approved in 2010 by the G20 in response to the global financial crisis and to reconfigure the approach to regulatory and risk matters (PWC, 2011) in the financial sector, in an effort to ease future economic shocks (KPMG, 2011, p. 7). Arguably, Basel III is expected to impact on the lending capacity of banks with the liquidity ratio requirements exerting pressure on the ability of banks to engage in short term lending (KPMG, 2011). Vecchi et al. (2013) contend that this has implications for banks' lending to PPP concessionaire companies, with the Basel III stability ratios making PFI loans more expensive (HM Treasury, 2012). The global financial crisis may therefore have caused a decrease in the number of lenders to PPP projects (World Bank, 2012, p.54) and in fewer projects reaching financial closure in addition to an increase in interest costs for PPPs (Farquharson and Encinas, 2010). This is also clearly apparent in Ireland as the global financial crisis has resulted in 24 projects being abandoned or postponed due to a dearth of finance and an increase in the cost of finance (Reeves, 2013, p.6-7).

According to a recent House of Commons (2010, p.5) report, finance costs for PFI increased by up to $33 \%$ in 2009 , and both bond and bank finance have been restricted substantially (Wagenvoort et al., 2010), with the increased financing costs impacting considerably on VFM (NAO, 2010). Additional regulatory changes may also have a negative effect on funding for infrastructure investment. These measures include the Solvency II Directive, which has implications for insurance firms in the EU, and the Alternative Investment Fund Managers EU Directive for asset managers (OECD, 2012, p.33).

A recent report by EPEC (2013a) confirmed that as a result of the financial crisis, PPP activity has fallen substantially in Europe. For 2012, the volume of PPP activity was at its lowest level for 10 years. During this period, PPP deals were closed in only nine countries. The cumulative value of these deals was $€ 11.7$ billion, with the transport sector accounting for the majority of PPP investment (EPEC, 2013a). Prior to the financial crisis in 2008, however, the value of PPP activity was approximately €29.6 billion, with 136 PPP projects (Kappeler and Nemoz, 2010 p.7).

\footnotetext{
${ }^{10}$ Basel III signifies the most significant regulatory changes that the banking sector has seen in decades. The primary aim of Basel III is to improve financial stability and to strengthen capital and liquidity requirements so that governments will not have to bail out banks in the future (PWC, 2011).
} 


\section{Risk and Uncertainties in PPP Projects}

Grimsey and Lewis (2005, p.376) point out that risk involves the assignment of probabilities and calculation of expected outcomes for a myriad of different scenarios. They argue that the possibility of different outcomes amplifies the difficulties in managing risk in PPP (Grimsey and Lewis, 2005). It can be very difficult to distinguish between risk and uncertainty and this has raised considerable debate in the academic literature (see for example, Froud, 2003; Broadbent et al., 2008). Risks can be quantified; however uncertainties tend to be more subjective and difficult to value (Grimsey and Lewis, 2005).

Demand risk emanates within the operational phase, but its pricing occurs before the PPP becomes operational. In road PPP projects there are a plethora of different risks such as demand, credit, termination, landowner, construction and operational risk, and the stakeholders will have different perceptions on what they consider to be the key risks. Risks can manifest themselves and become more profound over time in the PPP contract. The perceptions that stakeholders have on risk can change over time, particularly after a PPP project becomes operational. The treatment of qualitative items such as broad societal benefits in the PPP process is difficult to quantify. Pollock et al. (2004) recognise that the societal implications of risk transfer needs to be audited more in PPPs, while Broadbent et al. (2008) argue that more research is needed into the qualitative aspects of risk in PPPs.

The next section discusses these risk implications for payment mechanisms in road PPPs.

\section{Payment Mechanisms and their implications for the transfer and pricing of demand risk in road PPPs}


There are a number of different payment mechanisms that can be used in PPP roads, including hard tolls, availability payments and shadow tolls ${ }^{11}$ (Siemiatycki and Friedman, 2012). The payment mechanism chosen will have implications for how demand risk is managed in road PPPs. The transfer and pricing of demand risk deviates in each model which are now examined in turn.

5.1. Hard tolls are operated by the SPV, which bears demand risk. Such PPPs should be largely self sufficient with small operational and construction payments provided in some instances, whereby there is very little burden on taxpayer's funds. Hard toll PPPs may also provide adequate incentives for the SPV and encourage greater enterprise and performance because of their upside potential when demand levels exceed expected levels. This encourages the SPV to ensure a high quality road, with minimal queuing and traffic disruptions, in order to increase their traffic levels. The public sector through the contractual provisions for demand risk in Irish toll road PPPs also gain through revenue share when demand exceeds expected levels ${ }^{12}$ (NRA, 2012). Arguably, this encourages greater co-operation between the public and private sectors. If the requisite traffic does not arise on the scheme, users fees may be insufficient and increased toll levels, grants or subsidisation from the Government may be necessary (Acerete et al., 2010).

5.2. In availability based PPPs, demand risk resides with the public sector. A fixed unitary payment is paid by the Government to the SPV over the project's lifecycle, subject to the SPV meeting performance and availability criteria whereby there is less incentive for the SPV to improve performance. The level of traffic on the road will have no impact on this payment (Siemiatycki and Friedman, 2012). Unitary payments do not begin until the PPP becomes operational. In this arrangement, the SPV is also penalised if they close the road for a particular reason such as poor weather conditions or due to an accident. The onus is on the SPV to be proactive and deal with any problems such as maintenance and accidents as they arise. In more recent road schemes in the UK, availability and performance criteria have been used more frequently (Acerete et al., 2010).

\footnotetext{
${ }^{11}$ Shadow toll schemes are not being used in the Republic of Ireland.

12 A recent report by the CAG (2012) indicated that in 2011 the NRA received $€ 1.18$ million in terms of revenue share in toll road PPP contracts. A few of the interviewees in this study confirmed that revenue share is being achieved on the Dundalk Western Bypass and Kilcock Kinnegad schemes, but not on the Rathcormac-Fermoy scheme.
} 
5.3. Shadow tolls are financed through exchequer finance, which essentially results in the taxpayer paying for the PPP. These have been in operation in the UK for a number of years. In shadow tolls the sponsoring authority pays the private sector based on the type of vehicle and not just the number of road users per kilometre. This is necessary because the longer/heavier vehicles tend to do more damage which increases maintenance costs. Therefore, relative pricing for different types of demand is important as there are different incentives for the operator. The level and types of traffic influence the extent of the shadow toll payment and the private sector shoulder the downside demand risk. With a shadow toll, demand risk is arguably transferred to the SPV. However, in the UK, it is pointed out that the Highways Agency may assume demand risk if demand fluctuated in ways beyond the realm of control of the SPV (Edwards et al., 2004, p. 114-115). In such an arrangement, the procuring authority pays for the road to facilitate the users. With respect to shadow tolls in the UK, traffic estimates were found to be quite accurate (Edwards et al., 2004). Nonetheless, as with availability based schemes, the SPV is penalised if road availability, adequate safety levels, performance and traffic flow are not maintained (see Table 1 below for a comparison of the different payment mechanisms). The contract may be rescinded if the SPV does not manage the road appropriately (Edwards et al., 2004).

\section{INSERT TABLE 1 ABOUT HERE}

Some private constructors may prefer availability types of PPPs to hard tolls, as Hayford (2011) has recently indicated, because in shadow and availability based PPP models, demand risk is retained by the public sector.

\section{Demand Risk}

For the purpose of this paper, we examine demand risk under three distinctive headings; allocation and transfer of demand risk from the public to the private sector, pricing of demand risk by the SPV, and finally changing stakeholders perceptions' on the transfer and pricing of demand risk. We will next consider each of these issues in turn.

\subsection{Allocation/Transfer of Demand Risk in road PPPs}

Risk allocation is fundamental to the PPP process, as the overriding goal of the public sector is to optimally allocate risk rather than increase the actual level of risk transfer to the private sector (Corner, 2006). Hood et al. (2006, p. 48) state that in PPP projects 'the public sector will always 
be the risk bearer of last resort', essentially meaning the taxpayer retains the risk. Risk transfer is a very subjective process and involves the assignment of probabilities. It is the central tenet behind achieving VFM in PPPs. Hood et al. (2006) express concern that governments sometimes exaggerate the extent of transferred risk to the private sector, thus resulting in the private sector gaining excessive profits. Acerete et al. (2010) argue that risk transfer cost the UK Highways Agency considerably in UK road PPPs. Furthermore they point out that using private funds in roads has benefitted contractors, operators and their financiers as opposed to the taxpayer. Asenova and Beck (2010) believe that the senior debt financiers want to ensure that as many risks as possible in the PPP process are transferred to other parties, in order to minimise their exposure to risk, despite the subcontractors' capacity to assume the risks being questionable.

Many PPPs have failed across Europe due to demand risk being apportioned to the private sector (OECD, 2008). Jupe (2011) refers to problematic PPPs in the UK transport sector, and questions the Governments beliefs that these PPPs would lead to greater VFM and effective risk transfer. The highly controversial London Underground PPP, for example, required significant subsidies from the Government and $95 \%$ of the senior debt on the project was guaranteed by the Government. The PPP was a financial disaster and eventually had to be transferred back to the public sector (Jupe, 2011). Hard toll PPP failures have also been notable across Chile (Vassallo, 2006) and Spain (Acerete et al., 2009). In Australia, the Government did not intervene in the Cross City Tunnel project when demand failed to emerge and the inability of the SPV to pay the interest on the loans led to it going into administration (Johnston and Gudergan, 2007). Hard toll PPPs have performed poorly across Central and Eastern Europe too, with overoptimistic traffic estimates evident and Government intervention was required with many contracts renegotiated (Brenck, Beckers, Heinrich and Von Hirschhausen, 2005). Such Government intervention may be in the form of state guarantees, renegotiated contracts or transfers (Albalate and Bel, 2009). Perhaps a bigger danger in PPP contracts is where the SPV perceive that implicit guarantees may be provided (Shaoul et al., 2008) and sometimes companies may strategically underbid also because they enjoy a close relationship with the Government and feel that it will be easy to renegotiate the contract. In this regard, they may convince the Government to help them if low traffic levels are evident (Albalate and Bel, 2009). 
EPEC (2011) recognising the difficulties with funding infrastructure projects in Europe, recently published a document promoting state guarantees (SGs) ${ }^{13}$ for PPPs in order to improve the risk allocation process from the perspective of the SPV. Such guarantees are advocated for a number of reasons including, instilling confidence among funders, protecting the credibility of projects and they may also be used to mitigate project risks such as demand risk where lenders are apprehensive about potential revenue flow from the project. Although state guarantees are a very useful mechanism to reduce risk, EPEC are keen that optimal risk allocation and VFM are not affected by such guarantees (EPEC, 2011) because when they are implemented, the taxpayer is effectively shouldering the risk. As Acerete et al. (2010) suggest, political commitment is essential to ensuring private finance projects either have the requisite demand or receive subvention payments where necessary to ensure their long term viability. Demand risk can therefore be very much politically motivated in that Government may directly intervene in underperforming PPPs and bail them out (Acerete et al., 2010). Wettenhall (2007) argues that the SPV will often have considerable political influence which may undermine the extent to which underperformance in contracts is penalised. Such political clout for the SPV was evident in Spanish healthcare PPPs (Acerete et al., 2011). Shaoul et al., (2008) also discuss the cost of PPP failure using the Skye Bridge and Dartford Crossings examples where the Government ultimately bore significant risks and costs. They argue that, ultimately risk is a political decision (Shaoul et al., 2008) as toll schemes reward the financiers at the expense of the taxpayer (Shaoul et al., 2011).

One of the other changes taking place in roads PPP market, as a result of the financial crisis, seems to be the balance of risk distribution with more mixed toll mechanisms ${ }^{14}$ emerging and more revenue guarantees and government supports being provided on schemes (Kappeler and Nemoz, 2010).

\subsection{Pricing of Demand Risk in Road PPPs}

Pricing of demand risk in PPPs is usually undertaken by the private sector once they are allocated the risks in the PPP process and is directly related to estimating traffic levels. Traffic or

\footnotetext{
${ }^{13}$ According to EPEC (2011, p.5) "State Guarantees are defined as agreements under which a sovereign or assimilated entity ("Government") agrees to bear some or all of the downside risks of a PPP project".

14،"Mixed" tolls include a number of constellations whose payment structures may vary considerably in terms of risk allocation between the public authority and the private partner' (Kappeler and Nemoz, 2010, p. 26-27).
} 
revenue risk in PPPs is important to examine because toll revenue and the financial robustness of the PPP are contingent upon demand. In toll road PPPs, various factors will impact on demand such as economic growth, gross domestic product, development in the region and the risk of diversion to alternative routes. Demand risk has a profound effect on financial risk as revenue from tolls can help to meet interest repayments and is related to other risks such as macroeconomic, interest rate, residual value and operational risk.

Shaoul et al. (2006, p.263) point out that 'traffic flow forecasting is not an exact science' thus amplifying the difficulties in pricing demand risk. Bain (2009) outlines how many investors are deceived by traffic forecasts generated from traffic experts. The availability of historical data can impact on how accurately demand risk is priced by the SPV and generally the more aggressive they are on traffic volume, the greater the chance of them winning the contract. The senior lenders also have their own auditors and traffic advisers but the SPVs are normally far more aggressive than the lenders when pricing demand risk. Bain (2009) refers to a number of factors that lead to an optimism bias from an SPV perspective in traffic forecasting including inaccurate past trends, irrational consumers and assuming high initial demand levels. Vassallo (2007) points out that such opportunistic bids result from the strategic behaviour of bidders to win contracts rather than traffic modelling errors.

In the next section we examine some of the Government's key assumptions on these issues before explaining the research methods used in the study.

\subsection{Government Assumptions on the Transfer and Pricing of Demand Risk}

There have been significant guidelines produced in the Republic of Ireland on how risk should be managed in PPPs. In this section, we provide extracts from Government guidelines and publications which are available in the public domain on how demand risk should be transferred and priced in PPPs. The overriding view is that the Government expect that risk should be allocated equitably in the PPP process.

The Department of Finance claim that optimal risk transfer and VFM are at the fulcrum of successful PPPs. The Department of Finance (2006b, p.14) outline that: 
Risk is inherent in the management of all projects; In PPP projects achieving optimal risk transfer is one of the key means of securing value for money for the exchequer. The underlying principle in risk transfer in PPPs is that responsibility for the risks should rest with the party best placed to manage them. When considering risk transfer to the private sector, state authorities should keep this principle in mind and work towards the optimal level of risk transfer rather than a maximum level. The private sector will charge for each risk that they take on so there is a point at which risk transfer ceases to represent Value for Money.

The Department of Finance (2007, p.22) also claim that the use of toll revenue to remunerate the private sector should be considered if possible: 'A revenue stream from third party income ${ }^{15}$ can reduce the overall cost of funding a project and the potential to generate such income should always be considered, on a realistic basis'.

The global financial crisis has exacerbated the difficulties in obtaining funding for PPP projects and in light of the current financial difficulties, HM Treasury (2009, p. 9) have also recognised the importance of equitable risk transfer in order to ensure that the financial market will take on PPP projects in the future. The Department of Public Expenditure and Reform (2011, p. 46) acknowledge the difficulties with funding; however projects should not go ahead unless they lead to VFM

PPPs will continue to have a role to play in the delivery of key social infrastructure projects to meet remaining deficits in particular additional Schools Bundles and projects in the Health Sector. The private funding market has, however, been particularly challenging for the past number of years. Nonetheless, for those sectors where there are clear and pressing infrastructure requirements and where the PPP model can offer value for money, the Department of Public Expenditure and Reform, in consultation with the NDFA (as statutory financial adviser on all projects), will continue to work with Government Departments and agencies and other relevant stakeholders to help access private funding.

The Department of Finance (2007, p.17) stress the importance of the most accurately priced PPP bids being accepted.

\begin{abstract}
When considering the figures to include in the Value for Money Comparison, the sponsoring agency should use figures based on the demand forecasts that underpin third party income in the Public Sector Benchmark; the highest ranking bidder's demand forecasts should not be used. The NDFA will provide advice on how to address third party income in the Value for Money Comparison. (Italics added for emphasis)
\end{abstract}

\footnotetext{
15 Third party income refers to user fees in the form of toll revenues. In the bidding process the more income the SPV estimate they will receive from third party income, the lower the NPV of their tender will be.
} 
In essence, this suggests that, in their bid to secure the contract, the SPV should accurately price demand risk as opposed to under pricing it and allowing for a greater level of third party income.

\section{Research Methods}

Although case study research is not generalisable, it allows the researchers to evaluate key findings and emerging ideas (Nisar, 2007). Moreover Yin (1989) outlines that the use of multiple case studies facilitates comparisons and can improve reliability and validity. In-depth case studies were conducted with key stakeholders in three operational Irish PPP roads. Detailed case studies were developed through the examination of company reports, websites and documentation from which a detailed interpretative analysis was conducted. We also analysed qualitative and financial data pertaining to the case studies on Irish PPP websites such as http://www.nra.ie/ and http://ppp.gov.ie/. This coupled, with in-depth interviews with all of the relevant stakeholders in our case studies, has helped to gain a richer and deeper insight into these case studies.

Semi structured interviews with 38 key stakeholders were carried out between February 2008 and May 2012. The stakeholders were initially contacted by letter and subsequently by follow up letters, e-mails and phone calls to encourage them to participate in the research. Respondents were assured of their confidentiality and anonymity in the interviews. The results from the interviews were triangulated with the extensive secondary data which we analysed to support our arguments. All of the interviews were recorded using a tape recorder, and lasted approximately one to two hours. The interviewees provided an insight into their experiences and interactions with demand risk in operational toll road PPPs. All the interviews were transcribed and coded using the QSR Nvivo 9 Qualitative data package, which facilitated the analysis of Government publications with reference to the transfer and pricing of demand risk. A database was developed for each of the case studies and this proved to be very useful. This involves having a coherent structure for managing important documents (Yin, 1989). Within Nvivo, all of the interview data and information relating to each individual case study was saved under each case study code. A retrievable database helps to address reliability concerns with case studies as it provides the opportunity to access the evidence and not just using written details (Yin, 1989). 
For each of the three case studies, interviews were held with contractors, operators, financiers, equity financiers, SPV company members, technical advisors and traffic auditors (Details of the interview schedule are provided in tables 2 and 3). This helped to ensure consistency across our case studies. The traffic auditors/technical advisors are very important as they help to price demand risk in road PPPs. Interviews were also held with representatives of the NRA, National Development Finance Agency (NDFA) and Department of Transport Tourism and Sport as they are responsible for allocating and transferring demand risk in Irish toll road PPPs. Further interviews were also held with the Irish PPP unit, Irish Congress of Trade Unions and Irish Business and Employers Confederation as they also play a prominent role in Irish PPPs. Follow up interviews were held in May 2012 to help evaluate changing perceptions. Details of the follow up interviews are provided in table 3.

\section{INSERT TABLES 2 AND 3 ABOUT HERE}

\section{Empirical Findings of the Study}

The empirical findings of our case study research are provided within the context of the research questions stated in the introduction of this paper. The overall interview findings are summarised in Tables 4 and 5 for convenience reasons. Table 4 summarises the interview data on the transfer of demand risk in hard toll PPPs and Table 5 summarises the data on the pricing of demand risk in hard toll PPPs. We report and discuss our findings for each of these questions in turn. This is then followed by the differences in perceptions among the stakeholders interviewed and a comparison between stakeholders' perceptions and best practice advocated by the Government on the transfer and pricing of demand risk. Finally, we discuss changing stakeholders' attitudes on the management of demand risk and provide pointers to address some of the implications for PPP policy. Throughout the findings section, quotations obtained from the interviews across the case studies are used to support the empirical findings.

\section{INSERT TABLE 4 ABOUT HERE}

\subsection{Transfer of Demand Risk from the Public to the Private Sector}

As indicated in Table 4, the majority of the senior debt financiers believe that it is not effective to transfer demand risk to the SPV as happens in hard toll PPPs. The general consensus from the 
senior debt financiers across the case studies is that demand risk should be retained by the public sector and that shadow or availability type schemes are preferable as explained by one of the financiers on case study 2 :

Shadow tolls are more attractive to financiers. They are much less risky than hard toll projects. Demand risk is so difficult to estimate. (With) hard toll projects we have reached the conclusion that we are no longer interested in financing them, the risk is too significant.

Another senior debt financier involved in case study 1 pointed out a number of risks involved in hard toll roads and in particular the complexities involved with having to manage demand risk after it has been transferred to them:

\begin{abstract}
Hard toll roads are inherently risky. The incidence of default in projects that we have financed is very low because that will impact on how we formalise our risk strategy. We tend to focus on the less risky projects. We have been much more competitive on winning mandates where there are unitary based cash flows. These models are recession proof. We have been less competitive on those projects where you are taking more demand risk. That might explain why we finance only one toll road in Ireland. Demand risk is the black box risk in toll road PPPs.
\end{abstract}

Although the senior debt financiers had a preference for the availability type model, the general consensus from the senior debt financiers across all the case studies is that sovereign risk is now becoming a major issue. Akbiyikli et al. (2011) found that financiers in their study also questioned the ability of the exchequer to meet unitary payments.

The equity financiers in the SPV across all the case studies had an appetite for risk and assumed all of the downside risk as well as the upside potential associated with demand risk in toll road PPPs. An examination of the composition of the members of the SPV in the case studies provided in Appendix 1 shows that each of the case studies has a number of different equity investors. These investors include the contractors and operators on the schemes.

In contrast to the senior debt financiers, the equity financiers would support the Governments claims that there is equitable risk transfer in toll road PPPs. As indicated in Table 4 above, the majority of the SPV equity financiers seem to suggest that they are happy to assume this risk, due to the profits that can emanate from this type of payment mechanism and that this encourages the entrepreneurial spirit of the SPV. In this context, the equity financiers see hard toll roads as an opportunity to make more money as one of the equity investors on case study 3 explained: 
There is not too much incentive for a concessionaire in an availability payment PPP. They get the same money irrespective of how they perform... There is very little to play around with... It is true that there is not demand risk, but you also do not have the opportunity either. We look at demand risk as an opportunity, the more traffic you get the more money you get.

In contrast to the overriding belief from the equity investors that hard toll road PPPs are preferable, as highlighted by one of the equity investors on case study 2 , there is also some merit in the availability model where demand risk is not transferred by the public sector:

\begin{abstract}
Availability based roads are a lot more preferable because they are easier to get people interested in the project, particularly from a funding point of view. It is cleaner and it is neater and it has less risk. Toll road projects are risky projects for all involved, shareholders and funders.
\end{abstract}

It is possible in a PPP to transfer a multitude of risks to subcontractors such as design and construction risk. Demand risk, however, is not transferable by the SPV to a subcontractor. In hard toll roads, the SPV usually assumes this risk and the repayment of the loans to the senior lenders will be contingent on the project's robustness. As one advisor on case study 2 explained, the senior debt financiers want as many stakeholders as possible, including the contractors and operators, to have equity in the project as this encourages risk sharing including the sharing of demand risk and facilitates better risk management:

\footnotetext{
The senior lender wants everybody to be tied into the scheme including the advisors so everybody is sharing the risk... They are all equipped at managing risk and will manage risk to their own advantage.
}

Table 4 shows that all the procuring authorities and public sector organisations believe that the SPV is best equipped at managing demand risk and that demand risk should be transferred to the SPV where it is viable to do so and offers VFM. As one of the public sector officials explained, market forces significantly influence how the Government ultimately allocate demand risk:

\footnotetext{
Clearly if there are opportunities for us to do further toll roads we will do them. There are other options that we can use. There has to be sufficient demand... Toll road PPPs are a free road from the point of view of the exchequer.
}

A traffic auditor on case study 3 questioned the equitability of transferring demand risk to the SPV in hard toll PPPs, viewing a risk sharing approach as more appropriate:

I am not sure that the Government should be awarding contracts to optimistic bids. These projects are likely to come under stress. While some revenue risk should be taken by the private sector, some should be covered by the Government. 
The aforementioned findings suggest that the senior debt financiers are risk averse and believe it is more effective if demand risk is retained by the public sector. The equity investors are willing to assume demand risk due to the incentives it provides while the Government will seek to transfer demand risk in circumstances where it is viable to do so and provides VFM.

\subsection{Pricing of Demand Risk by the Private Sector}

We also sought to ascertain the interviewees' perceptions of the SPV's ability to accurately price demand risk when bidding for PPP contracts. This is an important question because the SPV must price demand risk accurately in order to effectively manage the whole project. However, in order to win the PPP contract in the first place, there are incentives for the SPV to underprice demand risk by allowing for a significant amount of third party income to be received in their bid.

\section{INSERT TABLE 5 ABOUT HERE}

As can be seen from Table 5, the senior debt financiers (0\%) unequivocally concur that the SPV price demand risk inaccurately in PPP. The senior debt financiers therefore usually also estimate traffic in hard toll PPP schemes. They employ traffic forecast auditors and technical advisors to review the traffic estimates that have been generated by the equity investors in the SPV. We found that the banks are always interested in the worst case scenarios on traffic and are reluctant to finance hard toll PPPs due to the significant risks involved and the difficulty in accurately pricing demand risk. We also found a change in attitude from some of the banks involved in our case studies in that they are beginning to look for revenue guarantees from the Government. Although such guarantees were not provided in our cases studies, in two recent PPP projects minimum revenue guarantees were provided to the SPV. ${ }^{16}$

A senior debt financier on case study 2 explained at interview the problems in pricing demand risk in hard toll roads:

Hard toll projects, we have reached the conclusion that we are no longer interested in financing them. The risks are too significant in them. The risks of trying to project traffic are significant. Probably in over half the projects we have done, we have been severely disappointed by the actual traffic we are getting on the road. In some cases traffic was $50 \%$ less.

\footnotetext{
${ }^{16}$ In the Clonee Kells toll road PPP, located in the Meath region of the Republic of Ireland, and the Limerick Port tunnel PPP, minimum revenue guarantees are provided by the Government to protect financiers.
} 
The Government should not accept forecasts which are strategically underbid and have an optimism bias, but as one of the senior debt financiers on case study 1 explained, the competitors' aggressive rather than accurate outlook in pricing traffic resulted in a loss of contracts for them:

\begin{abstract}
We have seen certain toll road projects, especially ones that we have not participated in, where we have said to the client, this is the cover ratio that we want you to have in your forecasts. These are the growth rates that we think are reasonable and they have lost the concession. In our view our client lost the contract not because they had done anything wrong but because the competitor has taken a much more aggressive outlook on traffic. We prefer not to be involved in a project where the contractor is expecting the lender to take an excessive outlook on traffic that is not actually supported by actual evidence.
\end{abstract}

The lenders apprehensiveness to pricing demand risk was highlighted by one of the traffic auditors on the same case study at interview:

\begin{abstract}
I don't think I have seen any case where the lenders have pushed the sponsor's forecasts up... You look at the risks from a different perspective when you work for the SPV and lenders. The lenders will often look for a $95 \%$ worst case scenario for the project. The sponsors will never ask us to provide that, so you must understand the assumptions are different. Sometimes we are asked to even provide a $99 \%$ worst case scenario by the lenders.... When we work for the sponsor they look for the best case scenario.
\end{abstract}

Once demand risk is transferred to the private sector in hard toll PPPs, it is essentially shared by the equity and debt holders. As explained by one of the equity financiers at interview on case study 3 , however, the majority of the equity financiers feel they are competent and have the expertise to accurately price demand risk:

\begin{abstract}
Demand risk is a risk we take. We like it. We have been operating motorways for many years. In our case we prefer the hard toll model. You are taking a big risk, but at the end you are getting a higher return...We are very competitive and aggressive in our pricing of demand risk. We have the expertise to manage that risk.
\end{abstract}

Although the public sector believe that the SPV are conservative in pricing demand risk, they recognise that some risk taking is necessary in order to win the PPP contract, which does not correspond with Government guidelines advocating that demand risk should be accurately priced. Conservative bids simply won't be successful according to this public sector official:

I think what you see more than anything is conservative approaches, certain banks depending on who they align themselves with will be conservative and certain bidders will be very conservative. They will bring down the traffic levels, just to be sure to be sure. And the trouble is they are going to lose the bid because they are being too cautious, so there is a level of intelligent risk taking that is necessary in order to win projects like this. 
The public sector finds it very difficult to say no to an optimistic tender, as reputable firms with considerable experience are bidding for the projects:

\begin{abstract}
We would look at their tender and we would take a view on the robustness of their tender. If we thought their tender was way off, we would make a decision, but that is a decision you make very carefully because these guys as I say are major firms and if they took a view they might say excuse me no, we want this job no matter what.
\end{abstract}

There were mixed views about the SPV's ability to accurately forecast and price demand risk by independent auditors. In two of the case studies concern was expressed about the SPV's ability to forecast accurately. In the third case study, one of the traffic auditors praised the traffic forecasting and pricing of demand risk by the SPV:

\begin{abstract}
I have seen traffic forecasts that are a lot worse. The client on this scheme are one of the most experienced toll road operators in the World....They are not messing about losing money on deals. They want to get good deals. They know they need to start with something that is reasonably good and I think that is what they did.
\end{abstract}

Despite the majority of the SPV equity investors expressing that they can price demand risk, in some cases, as indicated by one of the equity financiers on case study 2 , the private sector had difficulty in accurately estimating traffic flow because traffic forecasters both internal and external were often wrong and deviated considerably in their forecasts:

\footnotetext{
When I ask the guys to generate traffic, I want something that is optimistic but realistic. You are pushing the boundaries but you are not been absolutely stupid. I have done these projects before and there is no point in being over optimistic and the traffic never comes. It is a dark art, a difficult art. Hindsight is a wonderful thing but I think our tender was optimistic but achievable.
}

Some of the technical advisers explained that many traffic forecasts were revised downwards due to the inability of the SPV to price demand risk accurately and problems with their methodologies. Most of the interviewees across all our case studies think that the highly competitive nature of the Irish PPP market is encouraging the private sector to be aggressive when pricing demand risk. However, some disagreement is evident within the SPV partners when pricing demand risk. The senior debt financiers are very apprehensive about demand risk, whereas the traffic forecasters for the equity investors are clearly over optimistic when pricing risk. The traffic forecasters tend to overestimate the anticipated traffic volume. There was some concern that PPP projects are not being priced accurately to reflect the risks inherent in them, as indicated by one of the equity investors on case study 3 : 
The problem is that the competitors in the market are not seeing the PPPs as PPPs as such and therefore the premium that you are adding because you are buying so much more risk in a PPP contract has not been contemplated by other competitors....People don't care about the risk they are pricing...We are aggressive but we don't do stupid things.. We are not discounting the way other competitors are discounting.

One of the reasons perhaps for this, as explained by one of the advisors, is that the equity financiers within the SPV downplay the risks:

The SPV will assure everyone that there is no risk whatsoever and just sign up for it. The banks will go "No get a life and this is as risky as hell"...Any financier is always looking for some degree of comfort; they want to know the extreme downside.

The above findings suggest that the equity investors are satisfied to price demand risk and feel they have the capability to do so. In contrast, serious reservations were expressed by the senior debt financiers regarding the capability of the equity investors to accurately price demand risk. Interestingly, the public sector indicated that some intelligent risk pricing may be required by the SPV to be successful in winning contracts.

\title{
8.3. Changing stakeholder attitudes towards the transfer and pricing of demand risk
}

Our findings also suggest that stakeholders' attitudes may be changing in terms of risk transfer and possible Government intervention in hard toll PPPs. Demand risk is fully transferred to the SPV in hard toll PPPs, but some of the equity investors including an equity investor on case study 2 that we interviewed suggested that the Government may step in and renegotiate the contract to help the SPV should the PPP experience financial difficulty:

\begin{abstract}
Well the reality of it is and my argument is and also the way that it is shaping, is that ultimately if Road X was to start getting into problems then the Government would have to step in to deal with the funders. My view has always been that they are better off upfront saying right we will give you a commitment but that commitment will have certain legs to it... I think they hide behind it, all Governments hide behind this sort of; and say oh well it is recoursable; people are saying well we know ultimately that the Government will have to step in.
\end{abstract}

Similarly, an SPV manager, in one of the other case studies, who explained that the SPV aggressively price demand risk in PPP also expressed the belief that the Government should renegotiate the contract with them in the event of financial difficulty:

Letting businesses to fail is not good business for anybody. It is not good for the people who put in their equity, it is not good for the State, it is a bad signal because everybody got it wrong....I would say there is an argument to say well maybe the State needs to 
have a secondary position....here is the safeguards and that is where maybe the floors for traffic should be or maybe have subvention payments or distress intervention.

Although our findings indicate that the public sector prefer to transfer demand risk, we did find some evidence that suggests the public sector is changing its attitude in that they are becoming more concerned with the amount of risk transfer in road PPPs to the private sector:

We were only interested in toll based PPP's ..... free road essentially from the point of view of the exchequer with the user paying for it, and if the private sector was prepared to take on that risk then good luck to them but clearly we have to be careful to make sure that all the transferred risk is not so aggressive that we are going to leave companies in trouble.

Another public sector official outlined that there are now extra provisions included in the contracts to ensure that they are financeable. There is very little point in transferring excessive risk or having a contract that nobody wants to sign up to:

I think the reality is that if you are signing a PPP deal now that a number of things are different. Firstly, the margins on the debt have increased. At the moment these margins are a bit higher. Secondly, there are additional provisions included in the contracts to reflect the market's attitude at the moment. These contracts are very much driven by and reflected by market conditions. There is no use having a contract if nobody is going to sign it.

Shaoul et al. (2012a) refer to the reputational risk attributed to PPP failure and consistent with this, the last thing that the procuring authority wants to see is a project failing as they recognise that this would send bad signals to the market. Notwithstanding this any potential intervention would have to be carefully considered as public money is at stake and the procuring authority indicated they would expect any potential loans or aid to be repaid by the SPV. Furthermore the public sector is mindful that if they do intervene in a struggling project it may set a dangerous precedent as a public sector representative explained at interview:

\begin{abstract}
Would the Government step in? It is premature to know what the outcome of that would be, but it would be something that would be considered.... We don't want to see a project fail because we know that it is not good for Ireland. It would be bad for future investment. There are all these arguments as to why you would or would not do it. Equally we are not going to go and do something that leaves us exposed. We have got precedent as well, there are ten projects out there, and you know if you do something for one, you are exposing yourself to other projects involved.
\end{abstract}

These sentiments were echoed by one of the Government advisors in Irish PPPs who indicated that the Government may help the SPV when demand levels are low on the road:

The consortium may come back and in some way look to open up negotiations again if demand has completely fallen away, but hopefully that won't happen but it is in the back of your mind. 
The majority of the senior debt financiers indicated that more specific guarantees such as minimum revenue and loan guarantees may be necessary for them to participate in future toll road PPPs. This was illustrated by a senior debt financier at interview who indicated that they would not become involved in future PPP projects unless the state underwrites considerably more risk in the future:

\footnotetext{
We are now only focussing on guaranteed PPP projects going forward but that does not mean we won't finance infrastructure projects? No it does not. But now we will seek to be involved in just that part of the debt that has a direct guarantee from the Irish Government.
}

Another public sector official acknowledged that guarantees may be necessary due to funding problems:

As I have said to you already, the banks involved are much more risk averse, only relatively small projects have got away at the moment and the banks are raising issues about Government guarantees.

Prior work has indicated that many risks are transferred from financiers of PPP schemes to subcontractors. The above findings indicate that the public sectors understanding and treatment of risk transfer, and hence VFM, is a dynamic concept that has changed over time in the Republic of Ireland. The government is beginning to retain and share more of the risk in Irish road PPPs.. There are also some tentative suggestions from some of the interviewees that some risks may eventually be transferred back to the public sector. If the Government does provide a loan or subsidy to aid a struggling SPV, there is no guarantee it will be paid back, hence the taxpayer will have to unfairly shoulder the financial burden. The results of this study also suggest that a number of the equity investors also believe that the Irish Government may take on the risks if the projects were to experience financial difficulties. This would result in the risk being passed to the taxpayer to the benefit of some other players.

\section{Discussion and Conclusions}

This paper has been chiefly concerned with examining changing stakeholders' perceptions on the transfer and pricing of demand risk in Irish PPP roads. Within this context we examined perceptions on how demand risk is transferred from the public to the private sector, and priced by the SPV in PPPs. The findings are based on quotations from an extensive number of interviewees, and these have been selected as they highlight a general consensus on particular issues mentioned in the paper. We also compared our findings with Government assumptions on 
how demand risk should be transferred and priced in PPP. Where appropriate quotations representing an opposing minority view have been provided.

The findings of the study suggest that there are observable differences in the management of demand risk among the PPP stakeholders. Senior debt financiers are reluctant to finance hard toll PPPs due to their apprehensiveness over demand risk and are risk averse. Our findings suggest that stakeholders' perceptions, are changing and that the SPV, in light of the funding difficulties associated with PPPs at present, may require specific guarantees in the future in order to participate in road PPPs. The Government may be able to grant this, thus highlighting a possible significant change in its attitudes towards risk transfer. An example of this is evident in a recently signed road PPP deal in Ireland, whereby a standby credit facility was provided by the Irish Government through the National Pension Reserve Fund. This was necessary in order to ensure funding for the project (Sharma, 2013). Such changes have also been evident in a UK context where the Treasury established its Infrastructure Finance Unit in 2009 in order to provide loans for PPPs at comparable rates to commercial banks (Farquharson and Encinas, 2010). Furthermore, the UK Government announced a UK Guarantees programme worth $£ 40$ billion in July 2012 for a myriad of sectors, including transport, in order to assist funding given the current global financial difficulties (HM Treasury, 2012, p.25). The PF2 document published by the Treasury in 2012, represents a new approach by the UK government to PFI projects. The report was developed in response to a UK Government call for the assessment of PFI. This was in order to establish whether PFI was a good deal for the taxpayer and leads to VFM. This coupled with the global financial crisis has led the UK government to propose this new model to encourage infrastructural investment from the private sector. Under this process the government will also invest equity in PPP projects, which will lead to more risk sharing between the public and private sectors (HM Treasury, 2012).

PF2 is designed with the expectation of enticing long term investors such as pension funds as well as institutional investors into PPP projects. The increased use of EIB finance is also advocated by the Government in the report (HM Treasury 2012). Similar to the UK, alternative sources of finance, such as pension funds and the obtaining of additional funding from the EIB have been proposed recently by the Irish Government (See for example, Department of Public Expenditure and Reform, 2011 and 2012). The PF2 model will be financed by up to 20-25\% of risk capital, with equity invested from both the public and private sectors. More capital contributions from the Government at earlier stages of the projects are also proposed under the 
PF2 model (HM Treasury, 2012, pp81-83), and this is something the Irish Government may also want to consider, especially due to the number of Irish PPP projects that have been postponed or abandoned recently.

Demand risk is perceived to be effectively transferred to the SPV by the equity financiers and the public sector. The SPV equity holders appear to have an appetite for risk taking in hard toll roads due to the incentive to generate significant profits by getting more vehicles on the road. Senior debt financiers and consumer advisors, however, perceive demand risk that remains with the public sector to be more effective. This is interesting because we find that the term 'effectiveness' is perceived to mean different things to different stakeholders. While the effective risk allocation, according to senior debt financiers, means leaving demand risk with the public sector - because they perceive that the public sector can better control and bear this risk to the other financier's effectiveness seem to relate to managing the whole project generally. Although the senior debt financiers have a preference for the availability based model, we found evidence to suggest that they are also concerned with sovereign risk in terms of the Government's ability to meet unitary payments in future availability schemes.

There are also differences in how demand risk is perceived to be accurately priced by the SPV. The senior debt financiers and traffic auditors are more conservative in their traffic estimates than the SPVs. The equity investors within the SPV are aggressive rather than accurate in their pricing of traffic risk. They see traffic risk as an incentive within the PPP, and transferring this risk to the SPV creates an incentive to efficiently manage the project more generally. Winning the contract is their primary motive behind the under pricing of demand risk and we have some evidence to suggest that in one of the case studies unconventional traffic forecasting techniques were used by the SPV. The SPV members believe that the most optimistic bids are being chosen as opposed to the more realistic demand levels included in the Public Sector Benchmark (PSB). The rhetoric used by the Government in its guidelines on how demand risk should be priced in PPP appears to differ from what is actually occurring in reality. This raises the concern as to whether the Government actually care how accurately risk is priced in PPPs.

A clear strategy is needed to develop future policy developments in PPPs. This requires a thorough understanding of how risks are dispersed and managed, especially given the current financial uncertainty. Ireland's fiscal problems will impact on future PPP spending. The intention with PPP is that risks should be held by the party best able to manage them, and that 
the risk is priced accurately in the PPP contract. A key finding of our research indicates that, given the competitive pressures, it is possible to strategically under price risk in the contract in order to try win a bid. Moreover, senior debt financiers' preoccupation with reducing risk exposure through seeking minimum revenue and loan guarantees and transferring risk back to the public sector creates further policy implications for governments. The impact that these findings have on VFM, the public sector and ultimately the taxpayer needs to be assessed on an ongoing basis especially as Government guidelines state the importance of optimal risk transfer and PPP contracts being accurately rather than aggressively priced. Our findings also provide support to the view that the allocation of demand risk may be based on sub-optimal risk allocation, and individual stakeholders will try tweak this process in order to diffuse risk to their advantage. The inability of the equity and senior debt financiers in hard toll PPPs to transfer demand risk elsewhere ultimately may require the SPV to be rescued by the Government should financial difficulties emerge. Although the SPV may expect the government to intervene, the current difficulties in Irish public finances may limit any financial support that the Irish Government may potentially provide the SPV. The Government should also be aware of the political costs associated with toll road PPP failures; as such failures heighten the fears of taxpayers about the use and viability of such PPPs.

A recent report by the Comptroller and Auditor General (CAG) (2012) estimated that the Limerick Tunnel and Clonee Kells schemes have been expensive for the taxpayer costing $€ 5.2 \mathrm{~m}$ in 2011 and estimated to cost the Government $€ 6.7 \mathrm{~m}$ in terms of guaranteed traffic levels on these two schemes in 2012. In terms of revenue share, however, only $€ 1.18$ million was received on toll schemes in 2011. The CAG (2012) argue that there needs to be greater visibility in terms of future PPP commitments in the annual finance accounts and express the need for more VFM appraisals to be conducted on PPP projects in order to ascertain that they represent VFM. Future schemes in Ireland are likely to be availability based schemes with demand risk retained by the public sector (CAG, 2012).

In the PPP game it would appear that the taxpayers are the losers, supporting the earlier work of Shaoul et al., (2011). Indeed the recent report by HM Treasury (2012) acknowledged that PFI has been poor VFM for the taxpayer with excessive risk transferred to the SPV. Underwriting senior debt by the Government in hard toll PPPs may be necessary to ensure the future sustainability of the PPP toll road sector but at what cost to the tax payers and what cost to the pretence that the private sector contractors and financiers are taking on any risk at all. 
In order to help stimulate private sector investment and alleviate concerns regarding demand risk in the early stages of projects, the EIB have recently introduced a loan guarantee instrument for Trans European Transport Network projects. Under this guarantee some of the senior debt may be guaranteed by the EIB (EPEC, 2011). This scheme may result, as Jupe (2012) argues, in the Government underwriting too much risk in the PPP market.

Another important consideration is to evaluate whether the SPV believe that the Government will provide assistance in the event of the requisite traffic not emanating on the scheme and the PPP being in financial difficulty. The findings of this study would suggest that some of the SPV members believe that the Government could possibly intervene when demand levels are low. Such behaviour inevitably raises further questions about how risk is initially allocated in PPP and, consequently, it is also important to consider how it affects the accountability, VFM and transparency of the PPP process.

As PPPs become operational for longer time periods it would be interesting to examine if and why stakeholders' risk perceptions change over time. It would also be useful to ascertain how malleable these differences are between the stakeholders in order to discharge PPP accountabilities. The consequences of these different perceptions and the frictions that manifest from these differences require further attention in the future.

\section{APPENDIX 1}




\section{BACKGROUND TO THE CASE STUDIES}

\section{Case study 1: Dundalk-Western Bypass}

The N1/M1 Dundalk Bypass scheme was part of the second tranche of PPPs implemented by the Government. The operation and maintenance of the tolling facilities opened in 2003 are also included in this PPP contract. Under the PPP agreement the existing toll plazas and electronic toll collection had to be updated. The period for the contract is 30 years in total. The PPP opened on September $26^{\text {th }}, 2005,5$ months ahead of schedule. Celtic Roads Group (CRG) was successful in the tender for this project. CRG are required to invest and ensure that the road is at an adequate level prior to it been handed back to the NRA (www.nra.ie). CRG comprises of ACS Dragados, National Toll Roads and Royal Bam represented by Ascon. All these companies hold an equal $33 \%$ stake in the SPV Consortium.

\section{Case study 2: Rathcormac-Fermoy}

The NRA proposed this project in June 2000. Following a competitive tendering process, the contract was awarded to Direct Route LTD, comprising of a number of Irish companies such as Sisk, Lagan and Roadbridge and International companies such as Strabag and KBR. The contract is for a duration of 30 years and was signed in June 2004. Intolligent operate the toll plaza on behalf of Direct Route. They have an initial contract of 5 years to operate the toll plazas. This PPP has not been far away from controversy with many locals extremely opposed to it in the Watergrasshill area. A petition was signed and brought to that attention of the European Union. The road was officially opened on the $2^{\text {nd }}$ of October 2006. AIB and the EIB are the major financiers on this project. The project is financed through $80 \%$ senior debt and $20 \%$ equity (www.nra.ie). There is also a revenue share stipulation within the contract whereby once traffic levels exceed 21,000 per day, Direct Route pay the NRA a share of the profits.

\section{Case study 3: Kilcock-Kinnegad}

This project was initially included in the list of pilot PPP projects produced by the Government in 1999. It was the first PPP contract to be signed by the NRA in March 2003. The contract was completed before the expected commencement date and opened on the $12^{\text {th }}$ of December 2004 10 months ahead of schedule. The Eurolink Consortium was awarded this PPP contract. This consortium consists of Siac Construction Limited, a prominent Irish construction company and Cintra, a Spanish company with vast PPP experience worldwide. The contractor for the scheme is WestRoute Construction Joint Venture (www.nra.ie). The NRA has agreed to pay Eurolink $€ 146 \mathrm{~m}$ during construction and $€ 6 \mathrm{~m}$ in total during each year of operation. Eurolink and the 
NRA also have a revenue share agreement in place whereby the NRA will receive a proportion of revenue based on toll levels. Eurolink assume all downside risk on this project however (www.nra.ie).

\section{Acknowledgements}

The authors acknowledge helpful comments received from the participants of the European Risk Network Conference, University of Nottingham $3^{\text {rd }}$ September 2009; 33rd European Accounting Association Congress in Istanbul, Turkey, 19-21 May 2010; 34 ${ }^{\text {th }}$ European Accounting Association Congress in Rome, $20^{\text {th }}-22^{\text {nd }}$ April 2011; Irish Accounting and Finance Association Annual Conference, University of Ulster, 6-7 May 2010; Irish Accounting and Finance Association Annual Conference, University College Cork, 28 ${ }^{\text {th }}-29^{\text {th }}$ April 2011; Staff Seminar Queen's University Belfast $3^{\text {rd }}$ June 2011; American Accounting Association Annual Meeting $7^{\text {th }}-10^{\text {th }}$ August 2011, New Public Seminar, University of Edinburgh November 11th and constructive comments received from Tony Wall and Anne Stafford. All errors remain the authors' responsibility.

\section{References}


Acerete B, Shaoul J, Stafford A. Taking its Toll: The private financing of roads in Spain. Public Money and Management 2009; 29 (1):19-26.

Acerete B, Shaoul J, Stafford A, Stapleton P. The Cost of using Private Finance for Roads in Spain and the UK. The Australian Journal of Public Administration 2010; 69 (S1):S48-S60.

Acerete B, Stafford A, Stapleton P. Spanish healthcare public private partnerships: The 'Alzira model'. Critical Perspectives on Accounting 2011; 22 (6): 533-549.

Akbiyikli R, Dikmen S.U, Eaton D. Financing road projects by Private Finance Initiative:

Current Practice in the UK with a Case Study. Transport 2011; 26 (2):208-215.

Albalate D, Bel G. Regulating Concessions of Toll motorways: An empirical study on fixed vs. variable term contracts. Transportation Research 2009; Part A, 43 (2):219-229.

Alonso-Conde A.B, Brown C, Rojo Suarez J. Public Private Partnerships: Incentives, risk transfer and real options. Review of Financial Economics 2007; 16 (4):335-349.

Asenova D, Beck M. Crucial Silences: When accountability met PFI and finance capital. Critical Perspectives on Accounting 2010; 21 (1):1-13.

Bain R. Big Numbers Win Prizes, Twenty One Ways to Inflate Toll road Traffic and Revenue Forecasts, Project Finance International. 2009; 406 Thomson Reuters, London.

Brenck A, Beckers T, Heinrich M, Von. Hirschhausen C. Public Private Partnerships in new EU member countries of Central and Eastern Europe: An Economic Analysis with Case studies from the Highway Sector. Public Sector Management and Regulation Papers, EIB papers, 2005; 10 (2):83-111.

Broadbent J, Gill J, Laughlin R. Identifying and controlling risk: The problem of uncertainty in the Private Finance Initiative in the UK's National Health Service. Critical Perspectives on Accounting 2008; 19 (1):40-78.

Brown C. Financing transport infrastructure: For whom the Road tolls. The Australian Economic Review 2005; 38 (4):431-38.

Burger P, Tyson J, Karpowicz I, Coelho M.D. The effects of the financial crisis on PublicPrivate Partnerships. 2009 International Monetary Fund.

Claessens S, Dell'Ariccia G, Igan D, Laeven L. Cross country experiences and policy implications from the global financial crisis. Economic Policy 2010; 25 (62): 267-293.

Comptroller and Auditor General. Accounts of the Public Service 2012 Central Government and Revenue 2012 Online Available from http://audgen.gov.ie (Accessed April 2013).

Connolly $\mathrm{C}$, and Wall $\mathrm{T}$. The global financial crisis and UK PPPs. International Journal of Public Sector Management 2011; 24(6):533-542. 
Corner D. The United Kingdom Private Finance Initiative: The challenge of allocating risk. OECD Journal on Budgeting 2006; 5 (3):37-55.

Crotty J. Structural causes of the global financial crisis: A critical assessment of the new financial architecture. Cambridge Journal of Economics 2009; 33 (4): 563-580.

Demirag I, Khadaroo I, Accountability and Value for Money in Private Finance Initiative contracts. Financial Accountability and Management 2008; 24 (4):455-478.

Demirag I, Khadaroo I, Stapleton P, and Stevenson C. Public Private Partnership Financiers Perceptions of Risks. Institute of Chartered Accountants, Edinburgh, Scotland 2010.

Demirag I, Khadaroo I, Stapleton P, Stevenson C. Risks and the financing of PPP: Perspectives from the financiers. The British Accounting Review 2011; 43 (4):294-310.

Demirag I, Khadaroo I, Stapleton P, Stevenson C. The diffusion of risks in Public Private Partnership contracts. Accounting, Auditing and Accountability Journal 2012; 25 (8):1317-1339. Department of Finance. Guidelines for the provision of infrastructure and capital investments through public private partnerships. Online Available from http://ppp.gov.ie/keydocuments/guidance/central-guidance 2006a (Accessed19 ${ }^{\text {th }}$ November 2010).

Department of Finance. Assessment of Projects for Procurement as Public Private Partnership. Online Available from http://ppp.gov.ie/key-documents/guidance/central-guidance/ 2006b (Accessed $19^{\text {th }}$ November 2010).

Department of Finance. Value for Money and the Public Private Partnership Procurement Process. Online Available from http://ppp.gov.ie/key-documents/guidance/central-guidance/ 2007 (Accessed $19^{\text {th }}$ November 2010).

Department of Finance PPP website. http://ppp.gov.ie/ (Accessed March 2009).

Department of Public Expenditure and Reform. Infrastructure and capital investment 2012-2016, medium term exchequer framework. 2011 Online Available from http://per.gov.ie/wpcontent/uploads/Infrastructure-and-Capital-Investment-2012-2016.pdf (Accessed 8th January 2012).

Department of Public Expenditure and Reform. background note infrastructure stimulus July 2012 Online. Available from http://per.gov.ie/wp-content/uploads/Briefing-Note-17-7-12-

2_2.pdf (Accessed 8 ${ }^{\text {th }}$ August 2012).

Department of Transport Tourism and Sport. Bodies under the aegis of the Department, Online Available from http://www.dttas.ie/ 2010 (Accessed April 2010).

Edwards P, Shaoul J, Stafford A, Arblaster L. Evaluating the Operation of PFI in Roads and Hospitals. ACCA research report 2004 (84) Certified Accountants Educational Trust. London. 
EPEC. State Guarantees in PPPs, A guide to better evaluation, design, implementation and management. Online Available from http://www.eib.org/epec/resources/epec-state-guaranteesin-ppps-public.pdf, 2011 (Accessed 28 ${ }^{\mathrm{TH}}$ June 2011).

EPEC. Market Update, Review of the European PPP Market in 2012. Online Available from http://www.eib.org/epec/resources/epec, 2013a (Accessed May, 2013).

EPEC. What is EPEC. Online. Available from http://www.eib.org/epec/about/index.htm,2013b (Accessed 7th May 2013)

Farquharson E, Encinas J. Public Private Partnership Solutions. The UK Treasury Infrastructure Finance Unit: Supporting PPP financing during the global liquidity crisis, The International Bank for Reconstruction and Development 2010 Online Available from 531325/65983841268250365374/PPP_Solutions_01.pdf(Accessed 25 ${ }^{\text {th }}$ January 2012).

Froud J. The Private Finance Initiative: Risk uncertainty and the state. Accounting Organisations and Society 2003; 28(6):567-589.

Grimsey D, and Lewis M.K. Are Public Private Partnerships Value for Money? Evaluating alternative approaches and comparing academic and practitioner views. Accounting Forum 2005; 29 (4):345-378.

Hayford O. Where to now for Tollroad PPPs' Online Available from http://www.claytonutz.com/publications/videos/Where_to_now_for_toll_road_PPPs.page 2011 (Accessed 29th May 2011)

HM Treasury. Application Note: PPP Projects in current market conditions. Online Available from http://www.hm-treasury.gov.uk/ 2009 (Accessed 19 ${ }^{\text {th }}$ November 2010).

HM Treasury. A new approach to public private partnerships, Online Available from, http://www.hm-treasury.gov.uk/ 2012 (Accessed $7^{\text {th }}$ January 2013).

Hood J, Fraser I, McGarvey N. Transparency of risk and reward in UK Public Private Partnerships. Public Budgeting and Finance 2006; 26(4):40-58. Winter 2006.

House of Commons, Financing PFI projects in the credit crisis and the Treasury's response. 2010.

Ireland's National Development Plan, Ireland National Development Plan 2007-2013 Transforming Ireland. 2007 Online Available from http://www2.ul.ie/pdf/932500843.pdf (Accessed $9^{\text {th }}$ September 2009).

Johnston J, Gudergan S.P. Governance of Public-Private Partnerships: Lessons learnt from an Australian case. International Review of Administrative Sciences 2007; 73(4):569-582.

Jupe R. The Modernisation and Fragmentation of the UK's Transport Infrastructure. Financial Accountability and Management 2011; 27(1):43-62. 
Jupe R. The privatization of British Energy: Risk transfer and the state. Accounting, Organizations and Society 2012; 37 (2):116-129.

Kappeler A, and Nemoz M. Public private partnerships in Europe-before and during the recent financial crisis. Economic and Financial reports, 2010 European Investment Bank, No 2010/04.

KPMG. Basel iii issues and implications, Online Available from www. KPMG.com 2011 (Accessed $7^{\text {th }}$ February).

Li B, Akintoye A, Edwards P.J, and Hardcastle C. The allocation of risk in PPP/PFI construction projects in the UK. International Journal of Project Management 2005; 23(1):25-35.

National Audit Office. Financing PFI projects in the credit crisis and the Treasury's response, 2010, HC287, London. The Stationary Office.

National Audit Office. Lessons from PFI and other projects, 2011 (HC920), London, The Stationary Office. 2011

National Roads Authority. Information Note on National Roads Authority PPP Contracts, 2012,. National Roads Authority.

National Roads Authority website. www.nra.ie (Accessed March 2009).

Nisar T. Risk management in Public Private Partnership contracts, Public Organisation Review. 2007; 7(1):1-19.

OECD. Transport infrastructure investment: Options for efficiency, International Transport Forum. Online Available from http://www.internationaltransportfoum.org 2008 [Accessed March 2010].

OECD. Towards a green investment policy framework, mobilising private investment in sustainable transport. Online Available from http://www.oecd.org/env/cc/ 2012 (Accessed $9^{\text {th }}$ January 2013).

O’Sullivan, K.P.V, Kennedy T. What caused the Irish Banking crisis. Journal of Financial Regulation and Compliance 2010;18 (3):224-242.

Pollock A, Price D, Player S. Public risk for private gain? The public audit implications of risk transfer and Private Finance. Unison, London. 2004.

Price Waterhouse Coopers. Delivering the PPP Promise. A review of PPP issues and activity 2005; London: Price Waterhouse Coopers.

Price Waterhouse Coopers. A practitioners guide to Basel iii and beyond, 2011 Price Waterhouse Coopers. 
Public Private Informal Advisory Group. Framework for Public Private Partnerships:Working together for quality Public Services, 2001, Online Available from http://ppp.gov.ie/ [Accessed October 2010].

Public Works Financing. Survey of public private partnerships worldwide. Available from http://www.pwfinance.net/document/October_2011_vNov202011.pdf.2011;264.[Accessed

November 2012].

Reeves E. Public Private Partnerships in Ireland: A review of the experience. Paper presented to the Nevin Economic Research Institute, 2013 Dublin.

Roumboutsos A, Anagnostopoulos K. P. Public Private Partnerships in Greece: Risk ranking and preferred allocation. Construction Management and Economics 2008;26 (7):751-763.

Shaoul J, Stafford A, Stapleton P. Highway Robbery? A financial analysis of Design Build Finance and Operate in UK roads. Transport Reviews 2006; 26 (3):257-274.

Shaoul J, Stafford A, Stapleton P. Evidence- Based policies and the meaning of success: the case of a road built under Design Build Finance and Operate. Evidence and Policy 2007; 3(2):159179.

Shaoul J,Stafford A, Stapleton, P, MacDonald P. Financial black holes: Accounting for privately financed roads in the UK, Institute of Chartered Accountants of Scotland. Edinburgh. 2008.

Shaoul J, Stafford A, Stapleton P. Bridging the gap? Financing the Dartford and Skye bridges in the UK.Public Money and Management 2011;31(1):51-58.

Shaoul J, Stafford, A, Stapleton P. Accountability and corporate governance of Public Private Partnerships. Critical Perspectives on Accounting 2012a; 23(3):213-229.

Shaoul J, Stafford, A, Stapleton P. The Fantasy World of Private Finance for Transport via Public Private Partnerships, International Transport Forum OECD. 2012b; discussion paper,06.

Sharma S, The luck of the Irish. Infrastructure Journal News Blog, 2013Online Available from http://www.ijonline.com/Articles/85363/Preview (Accessed 30th May 2013) $3^{\text {rd }}$ May 2013

Siemiatycki M, Friedman J. The Trade offs of Transferring demand risk on urban transit Public Private Partnerships. Public Works Management and Policy 2012;17(3):283-302.

Thorhallsson B, Kirby P. Financial crises in Iceland and Ireland: Does European Union and Euro Membership matter. Journal of Common Market Studies 2012; 50(5):801-818.

Vásquez F, Federico P. Bank funding structures and risk: Evidence from the Global Financial Crisis. IMF working paper, 2012 WP/12/29.

Vassallo J.M. Traffic Risk Mitigation in Highway Concession Projects, the experience of Chile. Journal of Transport Economics and Policy 2006; 40(3):359-381. 
Vassallo J.M. Why Traffic Forecasts in PPP contracts are often Overestimated? EIB University Research Sponsorship Programme 2007. Online Available from http://www.transyt.upm.es/eiburs/txt/Traffic_Risk_Mitigation_Definitive.pdf (Accessed 30th May 2010).

Vecchi V, Hellowell M, and Gatti M. Does the private sector receive an excessive return from investments in health care infrastructure projects? Evidence from the UK. 2013 Health Policy. 110(2-3): pp 243-270.

Wagenvoort R, de Nicola C, and Kappeler A. Infrastructure finance in Europe: Composition, evolution and crisis impact. EIB Papers. 2010; 15(1): pp16-40.

Wettenhall R. ActewAGL: A Genuine Public Private Partnership?. The International Journal of Public Sector Management, 2007; 20 (5):392-414.

World Bank (2012) Public Private Partnerships reference guide. Online Available from http://wbi.worldbank.org/wbi/Data/wbi/wbicms/files/drupalacquia/wbi/WBIPPIAFPPPReferenceGuidev11.0.pdf (Accessed $9^{\text {th }}$ January 2013).

Yin R.K. Case Study Research, Design and Methods, Applied Social Research Methods Series, Sage Publications, London, United Kingdom, Vol.5, ISBN 0-8039-3470-X, 1989. 